\title{
The Implementation of Problem Based Learning (PBL) Based E-Book to Improve The Learning Outcome of Vocational High School (VHS) Students
}

\author{
Abigail Josephine Kusumatuty ${ }^{1}$, Baedhowi ${ }^{2}$, Tri Murwaningsih ${ }^{3}$
}

\begin{tabular}{l} 
ARTICLE INFO \\
\hline Article History: \\
Received 01.07.2018 \\
Received in revised form \\
21.08 .2018 \\
Accepted \\
Available online 01.10 .2018
\end{tabular}

\begin{abstract}
This study aims to find out the effectiveness of problem-based Learning (PBL)-based personnel administration e-book that can be accessed through website in smartphone or laptop and in order to find out the extent to which the e-book the result of learning students. The research method employed in this study was experiment research by comparing two classes of the class experiment and class control. Technique of analyzing data employed in this study was inferential statistic analy sis through normality test and homogeneity, followed with prerequisite test with t-test. T-test was conducted by comparing posttest score of two basic competencies for experiment and control classes and the result of comparison shows that the analy sis that had been conducted using t-test with tstatistic of 3.112 while ttable of 2.051 , or tstatistic $>$ ttable. It indic ated that there was a relevant difference between experiment and control class values so that the students' learning outcome in experimental class was better then the implementation problem-based learning (PBL)-based personnel administration learning e-book could improve the learning outcome of Vocational High School students.
\end{abstract}

(C) 2018 IJERE. All rights reserved

Keywords:

Effectiveness, E-book, Problem Based Learning, Learning Outcome

\section{INTRODUCTION}

Education is one of the containers that can be used to create human resources (HR) is qualified because education is always growing dynamically so that aspects and systems that exist in education can change along with the development of technology and time. At this time, the role of technology in the world of education is very much among the developments undertaken in order to prepare human resources that are able to compete (Warburton, 2003). Açişli, Yalçin, \& Turgut (2011) and Buckingham (2002) In the world of education there are many components or instruments that can be developed and integrated with technology, such as learning models, instructional media, instructional books and learning curriculum which results can be printed media and online media in the form of soft files.

Education innovation and development especially on learning is an important thing to be focused on improving learning quality (Kusuma, 2018). Smaldio and et al (2011) stated that one component that can be developed and integrated with technology is learning media that is not only in the form of a book but which has been modified by technology that is electronic book (ebook). In addition, the use of ebooks can help students to learn independently, explore students' understanding of the material to be learned, and improve reading and writing skills (Chen and Jang, 2013) and (Pierce, Richard and Jeremy, 2012). In addition to instructional media, learning models can also be developed and in this study researchers used a model of learning-based learning where the model has been adapted to the material to be learned in the learning process. Problem based learning is a learning model that requires students to process actively, creatively in solving a problem that exists in everyday life by relating the material to be learned in the learning process (Babich, Stankunas, and at all, 2016) and (Estrada and Conaw ay, 2012). Therefore, the combination of ebookbased learning media problem based learning in this study is expected to be more effective and efficient in the learning process.

The material used in the development of ebook is about the list of rank order (DUK) and the regulation of leave in which consists of a matter of case, a matter of pretest, posttest, and practice questions. Implementation of problem-based learning model for both materials is due to the number of teaching materials that will be used by students is still lacking and is expected with the tea ching materials students are able to follow the learning process well, can increase knowledge by studying and understanding the

1 abigailjosephine3@gmail.com, orcid.org/0000-0002-9147-7618

1,2,3 Universitas Sebelas Maret 
material that has been presented into the ebook that can be downloaded through the website (Abigail, 2018). Competence emphasized in the development of this ebook is expected to be student-centered ebook, making students more active and able to train students to learn independently (Andrea, Jenny, Joanna \& Amelia, 2016). Hosnan (2014) The process of learning problem based learning focuses on students solving problems or providing solutions of problems that have been given by teachers so that students are expected to understand and understand the material to be studied. Survey data obtained to explain the comparison of schools to be taken for research on the subjects of personnel administration with the subject of class XI the state Vocational High School (VHS) in Surakarta is as follows: the state VHS in Surakarta amounted to nine, schools that havebusiness management majors amounted to three, from three schools the random sampling was done so that two schools appeared and from two schools were interviewed and then the researchers found that there is only one school that can be used for research and development of ebook.

Problem based learning is a learning model uses an approach to authentic problems so that students can construct what is thought with the knowledge they have, students can develop skills and can increase self-confidence (Hosnan, 2014). In addition, the problem based learning model has other characteristics, namely training students to solve problems, providing new information that the teacher is only a facilitator to help students achieve the goals of the learning process and this model requires students to produce products such as: reports, transcripts and a video that explains the solution to the problems that have been discussed and in the discussion process students are required to take responsible learning so that if there are questions students are able to answer and explain clearly which is supported by clear evidence (Lazarinis, 2012). Ninlaw an in Sari (2018) stated that in addition to the teacher being a student facilitator, the teacher must also be able to make the classroom atmosphere comfortable and effective for learning with several criteria, including: (1) teachers are always professional in carrying out their tasks, (2) developing each competency existing, (3) able to innovate about teaching techniques, (4) able to understand the characteristics of each student, and (5) able to speak foreign languages.

Based on several definitions above, the problem based learning learning model is a learning model that requires students to want to process actively, where students are required to be creative in solving problems by connecting the subject matter received and in the learning process the teacher serves as a student facilitator to accompany. This is supported by several opinions from experts who state that the learning-based learning model focuses on students to solve a problem so that students will get new information or knowledge tolearn and in the process the teacher as a facilitator to accompany students, and - encourage students to be active (Chen, Lin, and Chang, 2011; Asyari, Muhdhar, Susilo and Ibrohim, 2016). In addition, Ramalhinho (2016) also added that PBL is very effective to be applied in the learning process because when the learning process takes place student learning discusses existing problem solving in everyday life by analyzing the problem first and providing solutions to the problem.

Considering the result of field observation, the fact shows that in learning process, the students are less interested in attending the personnel administration learning, because in the learning process teacher still uses conventional learning method or teacher center learning (TCL), has not maximized the use of media available at school due to the unavailability of book for personnel administration subject, and teachers as well as students look for materials in internet, and the students' learning outcome was less maximal because students have difficulty in searching for material any time the quiz, mid-semester test and final test will be held. Low learning outcomes can be seen based on the final semester exam scores in class XI AP 3 with an average value of 69 and the completeness criteria only reached $40 \%$.

Considering this phenomenon, the author is interested in developing PBL-based e-book learning media to make the students capable of attending the learning process well and the students' learning outcome can be maximal. PBL-based E-book for personnel administration subject emphasizes on the learning process giving the students the opportunity of participating actively in solving problem by means of thinking in group and training the students to defend their opinion (Jones, 2017). This is supported by statements from Shin Downing, and Ning (2011) which state that by applying PBL learning models will produce higher values for all subjects and in addition students also get scores on psychomotor aspects. This research novelty is the development of PBL-based e-book for personnel administration subject as there is no previous similar study on it. 


\section{Situation of the Problem}

Some previous studies have examined ebooks to improve learning outcomes but from some of these studies only focus on ebooks that rarely combine ebooks with existing learning models. To fulfill the requirements so that the ebook can be used in the learning process, the ebook must have: (1) a complex format that can be carried anywhere, (2) can attract students' attention, the ebook can always develop, (3) ebook can be used by anyone, (4) the process of copying and distributing is easy and inexpensive, and (5) encouraging greening of the environment.

Therefore, so that the ebook can improve student learning outcomes and facilitate students in the learning process, ebook development is combined using learning models that are in accordance with the material in school and in this study ebook development is combined with problem based learning (PBL) learning models.

\section{Aim of the Study}

The purpose of this research is to develop learning media in schools, one of them is by developing an ebook based on problem based hearing (PBL) which is then expected to improve student learning outcomes. In this objective framew ork, the answers to the following questions have been sought, namely: how can the development of ebook learning media significantly change the learning outcome variable.

\section{METHOD}

This research was conducted at the State Vocational High School (VHS) in Surakarta, Central Java because VHS are subjects of personnel administration and in Surakarta only have three VHS and all three have the same accreditation, namely is VHS 1, VHS 3 and VHS 6. In VHS 1 I found a problem that in these schools have no books for student learning that lead to student learning outcomes is low, whereas in the VHS 3 and VHS 6 should not be used for research on this period because the research schedule on the class is already full, so I decided to do some preliminary observations and research in VHS 1.

The sample in this study at VHS 1 Surakarta and the sampling technique used was random sampling while data collection techniques used pretest and posttest. This study was an experimental research conducted in two classes: experiment and control classes. In the experiment and control cla sses there are 31 students and all of the female gender. The first step is to determine the class that will be used as the experimental class and control class by direct observation, seeing the final value and the existence of equality tests for the two classes. The second step is the implementation of PBL-based ebooks for the experimental class and for the learning process control class using the usual learning model with the same material.

\section{Material}

The material presented in the learning process is list of employee ranks and Leave Rules and the following is a PBL-based ebook design:

Table 1. The application of problem based learning-based E-book (PBL)

Problem Based Learning (PBL)

1. Students find problem

2. Organizing the students to learn readily.

3. Guiding students in the learning process either individually or in group.

4. Students prepare report from the result of discussion with group and then present it.

5. Analyzing and evaluating the problem solving process.

(Arends, 2012; Hosnan, 2014; Abidin 2014)

\section{Problem Based Learning-based E-book (PBL)}

1. Creating group

2. Explaining the learning objective to be achieved.

3. Teacher tells the students to open the preexisting e-book in their own cellular phone in case problem sub chapter

4. Teacher tells the students to read and to understand the case problem.

5. Teacher tells the students to identify problem.

6. Members of group search for information or data to solve problem and then write the answer on a piece of paper and then submit it.

7. Individual group members work on pretest problem.

8. Group member representatives represent the result of 
discussion.

9. Teacher and students discuss each group's answer and then teacher explains the material to be studied.

10. Individual group members work on posttest problem.

11. Teachers and students draw a conclusion collectively,

12. Teacher evaluates the learning process. (Arends, 2012; Hosnan, 2014; Abidin 2014; Harris, 2011)

This study employed descriptive quantitative research method with prerequisite analytical test consisting of normality, homogeneity, and effectiveness tests with 31 students of Vocational High School (VHS) 1 in Surakarta, being the subject of research. This research employed problem instruments: pretest and posttest problems. The problem instrument w as prepared using some indicator criteria and the problem instrument used is presented in table below:

Table 2. Problem instrument used

\begin{tabular}{|l|l|}
\hline \multicolumn{1}{|c|}{ Indicator of Competency Achievement } & \multicolumn{1}{c|}{ Item } \\
\hline $\begin{array}{l}\text { Observing } \\
\text { (conducting an observation on the } \\
\text { problem given by teacher) }\end{array}$ & $\begin{array}{l}\text { Case Problems } \\
(1-5)\end{array}$ \\
\hline $\begin{array}{l}\text { Questioning } \\
\text { (short question needing no long thinking) }\end{array}$ & $1,4,5,6,11,13,15,17,21,23$, \\
\hline $\begin{array}{l}\text { Experiment } \\
\text { (question needing long thinking or logic) }\end{array}$ & $2,3,7,8,10,16,19,20,22,25$ \\
\hline $\begin{array}{l}\text { Association } \\
\text { (analyzing problem) }\end{array}$ & $3,9,12,14,18,24$ \\
\hline
\end{tabular}

Problem instruments above have undertaken feasibility test stage consisting of validity, reliability, variance, and difficulty level tests (Budiyono, 2013).

\section{Data Analyses}

For data analysis, in this study using the SPSS 22 statistical program. This research employed problem based learning model and before the research was conducted, the author should conduct statistic test first. Statistic test has two conditions: normally distributed and homogeneous.

Normality test was conducted to find out whether or not the sample used was distributed normally, using Kolmogorov Smirnov test with $\alpha=0.0050$, when the result obtained was not distributed nor mally, advanced test should be conducted by means of transforming data to obtain normal data. Homogeneity test $w$ as conducted to find out whether or not the sample to be compared came from the same population, and this test was conducted using Levene's test, while effectiveness test using t-test with criteria $\alpha=0.05$ at probability significance $(\mathrm{sig})<\alpha(0.05)$ and probability significance $(\mathrm{sig})>\alpha(0.05)$.

In this study, the author conducts an analytical prerequisite test consisting of: normality, homogeneity, and effectiveness tests. Normality test was used to find out whether or not the sample comes from normally distributed population and the sample can be said as coming from normally distributed population when $\alpha>0.050$; the result of normality test is presented below:

Table 3. Result of Normality Test

\begin{tabular}{cccc}
\hline \multicolumn{4}{c}{ Tests of Normality } \\
\hline \multicolumn{4}{c}{ Kolmogorov-Smirnova } \\
Experiment & Statistic & df & Sig. \\
Control & .155 & 31 & .054 \\
& .170 & 31 & .023 \\
\hline
\end{tabular}

From the data above, it can be seen that the experiment class is distributed normally as $\alpha>0.050$ or $0.054>0.050$, while the control class is not distributed normally as $\alpha<0.050$ or $0.023<0.050$. It can be stated that control class is not distributed normally, so that it is followed with advanced test by means of transforming the data, the result of which is presented below. 
Table 4. Result of Normality Test by means of Transforming Data

\begin{tabular}{cccc}
\hline \multicolumn{4}{c}{ Tests of Normality } \\
\hline \multicolumn{4}{c}{ Kolmogorov-Smirnova } \\
& Statistic & df & Sig. \\
Experiment & .155 & 31 & .054 \\
Trans_Control & .170 & 31 & .057 \\
\hline
\end{tabular}

Considering the data above, it can be seen that control class have been distributed normally with score of 0.057 , larger than 0.050 . Having conducted normality test and found that the sample used was distributed normally, homogeneity test was then conducted to find out whether or not the sample com pared came from the same population using Levene's test with $\alpha=0.05$. The result of homogeneity test is presented below.

Table 5. Result of Homogeneity Test

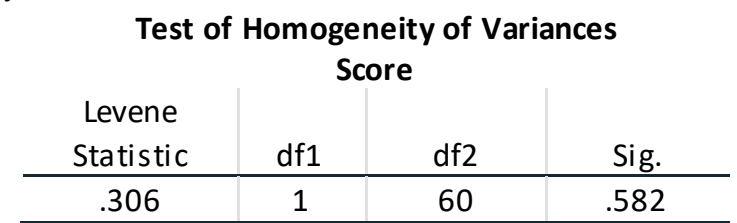

Considering the data presented in the table above, it can be seen that the sample compared came from the same population with significance value of 0.582 meaning that the score is larger than the specified score, 0.05 .

\section{FINDINGS}

Test in analytical prerequisite is effectiveness test conducted using $\mathrm{t}$-test to examine the effectiveness of personnel administration learning e-book that will be used with criteria $\alpha=0.050$. $\mathrm{H}_{0}$ is supported when $(\mathrm{sig})>\alpha 0.050$, while $\mathrm{H}_{0}$ is not supported when $(\mathrm{sig})<\alpha 0.050$. The result of effectiveness test is expressed below.

Table 6. Result of Effectiveness test in Experiment Class

\begin{tabular}{cc|c|c|c} 
& \multicolumn{3}{c}{ Paired Samples Statistics } & \\
& Mean & N & $\begin{array}{c}\text { Std. } \\
\text { Deviation }\end{array}$ & $\begin{array}{c}\text { Std. Error } \\
\text { Mean }\end{array}$ \\
\hline Pretest & 74.2903 & 31 & 4.16488 & .74803 \\
\hline Posttest & 87.5161 & 31 & 3.37511 & .60619 \\
\hline
\end{tabular}

From the data above, it can be found that the mean score of experiment class increases from pretest (74.29) to posttest (87.51). Meanwhile, the result of effectiveness test for control class is as follow s:

Table 7. Result of Effectiveness test in Control Class

\begin{tabular}{cc|c|c|c}
\multicolumn{4}{c}{ Paired Samples Statistics } \\
& Mean & $\mathrm{N}$ & $\begin{array}{c}\text { Std. } \\
\text { Deviation }\end{array}$ & $\begin{array}{c}\text { Std. Error } \\
\text { Mean }\end{array}$ \\
\hline Pretest & 68.3548 & 31 & 4.55008 & .81722 \\
\hline Posttest & 78.1935 & 31 & 4.85400 & .87180 \\
\hline
\end{tabular}

From the data above, it can be seen that the mean score of control class also increases from 68.35 to 78.19 , but this improvement is not as much as that in experiment class. It indicates that the mean score of experiment class is higher than that of control class. Then, to prove whether or not there is a significant difference of learning outcome betw een experiment and control class, obtained results that homogeneity test with sig (p) value in Levene's test for equality of variances $>0.05,0.582$; therefore it can be said that the data is homogeneous and there is no variant comparison. When the data is homogeneous, $t$ statistic value in table (T) is $3.112>2.051$; thus, there is a significant difference of scores as the difference of pretest scores between 
experiment and control class is $74.29-68.35=5.94$, while that of pretest is $87.51-78.19=9.32$, and the range of variance score at confidence level of $95 \%$ is between 0.910 and 4.186 .

\section{RESULT, DISCUSSION, AND SUGGESTIONS}

This study examines how the application of ebook based problem based learning (PBL) learning model is expected to improve student learning outcomes. Research findings show that the implementation of PBLbased ebooks is effective to be applied to the learning process and can improve student learning outcomes. There are several previous studies about ebooks such as research conducted by Shamir (2009) discussing the process and learning outcomes after using the ebook. The learning process that is carried out is very fun and effective so as to make it easier for students to receive learning materials well and learning goals can be achieved so that students get satisfactory learning outcomes by using an ebook in combination by a model of learning that has been adapted to the material.

Yalman (2015) conducts research on seeing how ebooks are used in the learning process at the college level. This study was carried out on students in universities with 1179 students coming from the education faculty and in this study using qualitative and quantitative methods simultaneously. The results of this study is that using an ebook can facilitate students in the learning process to understand the material to be delivered. This research is almost the same as the research that the researchers did only differently in the place of its implementation and the implementation of the ebook. Research conducted by researchers applies the ebook to personnel administration subjects while the research conducted by Yalman is applied to the existing library systems in universities.

Research on the use of ebooks is still ongoing, one of which is done by Letchumanan and Muniandy (2016). They conduct research on how mathematics postgraduate students use ebooks for learning activities. In this study explained that the use of ebook is very helpful for students to find relevant information in the learning process so that it can improve student learning outcomes. In addition, research conducted by Kouis and Konstantinou (2014) also added that the use of ebooks is a new innovation that can replace printed books because with the existence of an ebook can provide several advantages and can always be updated. Suharta and Luthan (2013) also mentioned that one learning model that is suitable to be applied in the ebook is a problem based learning (PBL) learning model because with the learning model students can develop creativity, a sense of democracy and the existence of an ebook can increase greening due to use few er print books.

In addition, Karami, Karami and Attaran (2013) stated that teachers in the learning process integrate PBL learning models with ICT in solving problems can develop knowledge of professional content and teaching skills than those who only use ICT. Burris and Garton (2007) also stated that by applying PBL learning models not only can improve student learning outcomes but also can improve critical thinking and content knowledge among students and Farenta, Sulton and Setyosari (2016) added that with the learning process using media learning is considered to be very effective and valid so as to facilitate students to understand and understand the material to be delivered by the teacher. PBL learning model is a learning model that is strategy in effective learning so that it can increase students' knowledge in the learning process (Preeti, Ashish, and Shriram, 2013). Pant (2011) states that the availability of ebooks reaches $17 \%$ and this percentage is higher than the availability of printed books that only meet $5-15 \%$, for this research seeks to provide interesting learning media so students can feel helped. This statement is supported by $\mathrm{Wu}$, and Chen (2011) which states that students also often use ebooks for study and research purposes, the ebook is used as a learning resource and additional references.

Based on the results of research that has been done, it can be concluded that ebook based problem based learning is effective to be applied in the learning process so that it can improve student learning outcomes. This is shown through the effectiveness of the e-book based on the increase in the results of the pretest that obtained an average score of 74.29 while the posttest score obtained an average value of 87.52, besides the effectiveness of the e-book was also supported by statistical calculations that the significance value generated amounting to 0.003 and the value is less than 0.05 , which means that $\mathrm{H}_{1}$ is accepted, which means that there is a difference between the average value of the experimental class and the control class. 
These results indicate that the application of e-book learning based on problem based learning is effective for improving student learning outcomes. This research is only limited to assessing student learning outcomes by implementing an ebook based problem based learning on personnel administration subjects at VHS 1 Surakarta.Suggestions for further research are to expand the subject matter and expand the school that will be used for research.

\section{REFERENCES}

Abidin. (2014). Desain sistem pembelajaran dalam konteks kurikulum 2013. Bandung: Refika Aditama.

Abigail, J., K. (2018, 4 Maret). E-book mata pelajaran administrasi kepegawaian berbasis problem based learning. Diperoleh 15 Agustus, dari https://www.slideshare.net/abigailjosephine/ebook-administrasikepegawaian-untuk-smk-kelas-xi

Açişli, S., Yalçin, S.A., \& Turgut, U. (2011). Effects of the 5E learning model on students' academic achievements in movement and force issues. Procedia-Social and Behavioral Sciences, 15, 2459-2462.

Andrea, Jenny, Joanna \& Amelia. (2016). Using E-books to create shared learning experiences between students of differing abilities. Journal of Occupational Therapy, Schools, \& Early Intervention. 9(1), 1214 .

Arends. (2012). Learning to teach, ninth edition. Americas, New York: McGraw-Hill Companies, Inc.

Asyari, M., Muhdhar, M. H. I. A., Susilo, H., \& Ibrohim. (2016). Improving critical thinking skills through the integration of problem based learning and group investigation. International Journal for Lesson and Learning Studies, 5(1), $36-44$.

Babich, S. \& Stankunas, M. (2016). The implementation of problem based learning in health service management training programs: Experience from Lithuanian University of health sciences. Journal of Leardership in Health Services, 29(4): 390-421.

Budiyono. (2013). Statistika untuk penelitian. Surakarta: UNS Press.

Buckingham, D. (2002). Media education: A global strategy. Media Culture Online, 1-22.

Buris, S. \& Garton, B.L. (2007). Effect of instructional strategy on critical thinking and content knowledge: using problem based learning in the secondary classrom from Texas Tech University, University of Missouri. Journal of Agricultural Education. 48(1) 106-116.

Chen, H.Y. \& Jang, S.J. (2013).Menjelajahi alasan menggunakan buku listrik dan pengetahuan teknologi pedagogi dan pengetahuan matematika dasar taiwan dan guru sains. Journal TOJET: Teknologi Pendidikan, 12(2): 131-141.

Chen, K. N., Lin, P. C., \& Chang, S. S. (2011). Integrating library instruction into a problem-based learning curriculum. Aslib Proceedings: New Information Perspectives, 63(5), 517 - 532.

Chen, S. \& Wu, M. (2011). Graduate student's usage of and attitudes towards e-books: Experiences from Taiwan. Department of Library and Information Science, National Taiwan University, Taipe, Taiwan. 45(3), 294-307.

Estrada, P. D. M. dan Conaway, R. N. (2012). E-books: The next step in educational innovation. Business Communication Quarterly, 75(2): 125-135.

Farenta, A. S., Sulton, Setyosari, P. (2016). Pengembangan E-module berbasis problem Based learning mata pelajaran kimia untuk siswa Kelas X SMA Negeri 8 Malang. Jurnal Pendidikan: Teori, Penelitian dan Pengembangan, 1(6), 1159-1168.

Harris, E.G dan Babin, B. J. (2011). South-Western cengange learning. CB2.USA.

Hosnan. (2014). Pendekatan saintifik dan kontekstual dalam pembelajaran abad 21 (pp.1-366). Bogor: Ghalia Indonesia. 
Jones, G., H. (2017). Mental health student nurses' satisfaction with problem based learning: A qualitative study. The Journal of Mental Health Training, Education and Practice. 12(2), 77-89.

Karami, M., Karami Z., \& Attaran, M. (2013). Integrating problem based learning with ICT for delevoping trainee teachers' content knowledge and teaching skill. International Journal of Education and Development using Information and Communication Technology, 9(1) 36-49.

Kouis, D., dan Konstantinou, N. (2014). Electronic textbooks advantages and challenges for the Hellenic higher education and publishing community. Library Review, 63(6/7), 531-543.

Kusuma,E.D., Gunarhadi \& Riyadi (2018). The development of problem-based quantum learning model in elementary school. International Journal of Educational Research Review,3 (3), 9-16.

Lazarinis. (2012). Cultural data and semantic technologies: Teaching XML annotation through a guided problem based learning approach. Journal of The Electronic Library. 30(5),635-670.

Letchumanan, M., dan Muniandy, B. (2016). How mathematics postgraduate students use mobile e-book? Library Hi Tech News, 33(7), 6-7.

Pant, S., J., A. (2013). Availability of E-books in science: Case study of university of dehli. The Electronic Library, 31(3), 313-328.

Pierce, Richard Fox, Jeremy.(2012). Vodcast dan Latihan Pembelajaran Aktif dalam Sebuah “Flipped Kelas" Model Modul Farmakoterapi Ginjal. Desain Instruksional dan Jurnal Penilaian, 76(10), 196-203.

Preeti, B., Ashish, A., \& Shriram, G. (2013). Problem based learning (PBL) - An effective approach to improve learning outcomes in medical teaching. Journal of Clinical and Diagnostic Research. 7(12), 2896-2897.

Ramalhinho, A., G., H. (2016). Teaching distribution planning: a problem-based learning approach. International Journal of Logistics Management. 27(2), 1-26.

Sari,N., Santoso,S. \& Murtini,W. (2018) .Students' responses tow ards D-Pbl learning model in the material of payment system and means of economic exchange. International Journal of Educational Research

Review,3(3),17-22.

Shamir, A. (2009). Processes and outcomes of joint activity with e-books for promoting kindergarteners' emergent literacy. Educational Media International, 46(1), 81-96.

Shin, Downing, \& Ning. (2011). Impact of problem based learning on student experience and metacognitive development. Journal of Multicultural Education \& Technology. 5(1), 55-69.

Smaldino, Sharon, E., Deborah, L.L., \& James, D. R. (2011). Instructional technology and media for learning: Teknologi pembelajaran dan media untuk belajar. Terj. A. Rahman. Jakarta: Kencana Prenadamedia Group.

Suharta \& Luthan, P. L. A. (2013). Application of cooperative problem based learning model to develop creativity and foster democracy, and improve student learning outcomes in chemistry in high school. Journal of Education and Practice, 4(25), 55-60.

Warburton, K. (2003). Deep learning and education for sustainability. International Journal of Sustainability in Higher Education, 4(1), 44-56.

Yalman. (2015). Education faculty students views about use of e-book. Journal of Distance Education. 16(10), 326-332. 